https://helda.helsinki.fi

\title{
Late flowering time enhances insect pollination of turnip rape
}

\section{Toivonen, Marjaana}

2019-05

Toivonen, M , Herzon , I , Rajanen , H , Toikkanen , J \& Kuussaari , M 2019 , ' Late

flowering time enhances insect pollination of turnip rape ' , Journal of Applied Ecology , vol.

56 , no. 5 , pp. 1164-1175 . https://doi.org/10.1111/1365-2664.13349

http://hdl.handle.net/10138/310726

https://doi.org/10.1111/1365-2664.13349

acceptedVersion

Downloaded from Helda, University of Helsinki institutional repository.

This is an electronic reprint of the original article.

This reprint may differ from the original in pagination and typographic detail.

Please cite the original version. 
2

3 Marjaana Toivonen $^{\mathrm{a} 1}$, Irina Herzon ${ }^{\mathrm{b}}$, Hanne Rajanen ${ }^{\mathrm{c}}$, Jenni Toikkanen ${ }^{\mathrm{a}}$, Mikko Kuussaari $^{\mathrm{a}}$

4

$5{ }^{a}$ Finnish Environment Institute (SYKE), Biodiversity Centre, Latokartanonkaari 11, Fl-00790 Helsinki,

6 Finland

7 University of Helsinki, Department of Agricultural Sciences, P.O. Box 27, FI-00014 University of 8 Helsinki, Finland

9 ' University of Helsinki, Department of Biosciences, P.O. Box 65, Fl-00014 University of Helsinki, 10 Finland

$12{ }^{1}$ Corresponding author: Marjaana Toivonen, Finnish Environment Institute, Biodiversity Centre,

13 Latokartanonkaari 11, Fl-00790 Helsinki, Finland. Tel.: +358443488349. E-mail:

14 marjaana.toivonen@ymparisto.fi

15 
1. Ecological intensification has been proposed as a strategy to mitigate the impacts of conventional intensive land use on pollinators and insect pollination. However, research has concentrated on the effects of land management on pollinator abundance and diversity, while studies directly measuring pollination services are still lacking for many crops and regions.

2. This study examines the effects of landscape heterogeneity, pesticide use intensity and flowering time on insect pollination of turnip rape (Brassica rapa ssp. oleifera), a major oil crop at high latitudes. The field experiment included monitoring pollinator visits on turnip rape flowers and measuring yield in 34 spring-sown turnip rape fields in Southern Finland. The fields were situated in two landscape types that differed in the cover of arable land and represented independent gradients of pesticide use intensity and flowering time.

3. Based on flower visits and number of seeds per silique, turnip rape was best pollinated in fields with late flowering time. The result suggests a temporal mismatch between crop flowering and the availability of pollination service in early sown fields. The increase in flower visits during summer was steeper among fields with low than high pesticide use, possibly due to a faster colony growth of important bee pollinators.

4. Pollinator community in turnip rape fields was more diverse in heterogeneous landscapes with less arable land than in homogenous field-dominated landscapes, suggesting higher stability of pollination services in diverse landscapes.

5. Total yield per plant was positively related to pesticide use intensity. The relationship between insect pollination and total yield was weakened by high compensation capacity of turnip rape, the plants producing more flowers under poor pollination.

6. Synthesis and applications. Crop pollination can be enhanced by shifting sowing time to better match crop flowering to the peak availability of the most important pollinators. 
Reduced pesticide use may also enhance pollination services but can lead to the total yield reduction due to pests. This highlights the need for pollinator-friendly pest control methods to maintain turnip rape yields while conserving pollination services.

\section{Tiivistelmä (Finnish abstract)}

1. Maatalouden ekologista tehostamista on esitetty strategiaksi, jonka avulla intensiivisen maankäytön kielteisiä vaikutuksia pölyttäjiin ja hyönteispölytykseen voidaan hillitä. Tutkimukset maankäytön vaikutuksista viljelykasvien hyönteispölytykseen kuitenkin puuttuvat yhä monilta viljelykasveilta ja alueilta.

2. Tämä tutkimus tarkasteli maiseman monimuotoisuuden, torjunta-aineiden käytön ja kukinta-ajan vaikutusta rypsin hyönteispölytykseen. Peltokokeessa seurattiin pölyttäjien vierailuja rypsin kukilla ja mitattiin satoa 34 kevätrypsipellolla Uudellamaalla. Pellot sijaitsivat kahdessa maisematyypissä, joista toinen oli peltovaltainen ja toinen monimuotoisempi ja vähemmän peltoa sisältävä. Lisäksi pellot erosivat toisistaan torjuntaaineiden käytön ja kukinta-ajan suhteen.

3. Pölyttäjien kukkavierailut ja siementen määrä per litu olivat korkeimmillaan myöhään kukkineilla rypsipelloilla, mikä kertoo hyvästä pölytyksestä. Tuloksen perusteella aikaisin kylvetyt rypsipellot saattavat kukkia liian aikaisin pölyttäjien saatavuuden näkökulmasta. Voimakkaimmin pölyttäjien määrä lisääntyi kesän aikana niiden peltojen joukossa, joilla ei käytetty torjunta-aineita. Mahdollinen selitys on, että tarhamehiläisten ja kimalaisten yhdyskunnat kasvoivat nopeimmin näiden peltojen läheisyydessä.

4. Pölyttäjien monimuotoisuus oli suurempi monimuotoisessa kuin peltovaltaisessa maisemassa, mikä parantaa pölytyspalvelun vakautta muuttuvissa olosuhteissa. 
6

5. Kokonaissato per kasvi nousi torjunta-aineiden käytön lisääntyessä. Hyönteispölytyksen ja sadon välistä yhteyttä heikensi rypsin hyvä kompensaatiokyky, jonka ansiosta heikosti pölyttyneet kasvit tuottivat enemmän kukkia.

6. Yhteenveto ja sovellukset. Viljelykasvin pölytystä voi parantaa säätämällä kylvöaikaa siten, että kasvin kukinta ajoittuu tärkeimpien pölyttäjien runsaushuippuun. Torjunta-aineiden käytön vähentäminen voi parantaa pölytystä mutta laskea samaan aikaan satoa tuholaisten ja rikkakasvien lisääntymisen takia. Pölyttäjäystävällisten kasvinsuojelukeinojen kehittäminen on tärkeää korkeiden rypsisatojen ja pölytyspalveluiden säilymisen kannalta.

\section{Keywords}

bees, ecological intensification, flower visitation, landscape heterogeneity, pesticide use, pollinators, syrphid flies, turnip rape 
Pollinator decline threatens biodiversity, ecosystems functioning and human well-being worldwide (Potts et al., 2016). Globally, over $75 \%$ of all food crops rely, at least partly, on animal pollination

(Klein et al., 2007). Over the past 50 years, agriculture has become more dependent on insect pollination (Aizen, Garibaldi, Cunningham, \& Klein, 2009), while yields of insect-pollinated crops have increased at a lower rate and become more variable than yields of wind-pollinated crops, suggesting increasing pollination deficits (Garibaldi, Aizen, Klein, Cunningham, \& Harder, 2011).

Among the most important drivers of pollinator decline are habitat loss and degradation due to conventional agricultural intensification (Potts et al., 2016). The simplification of agricultural landscapes, loss of natural and semi-natural habitats, and herbicide use reduce floral and nesting resources of pollinators (Svensson, Lagerlof, \& Svensson, 2000; Gabriel \& Tscharntke, 2007; Baude et al., 2016). Pollinators also suffer from insecticides, which have both lethal and a broad range of sublethal impacts (Godfray et al., 2015; Pisa et al., 2015). Neonicotinoids, the most widely used group of insecticides worldwide (Wood \& Goulson, 2017), have been reported to reduce wild bee populations (Goulson, 2015; Rundlöf et al., 2015; Woodcock et al., 2017; Arce et al., 2017) and crop pollination services provided by them (Stanley et al., 2015). The negative effect is emphasized in landscapes with low cover of natural and semi-natural habitats (Park, Blitzer, Gibbs, Losey, \& Danforth, 2015), and scarce floral resources (Goulson, Nicholls, Botías, \& Rotheray, 2015). In the European Union, outdoor use of three most widely used neonicotinoids (clothianidin, imidacloprid and thiamethoxam) has been restricted since 2013 , and was completely banned recently (European

102 Commission, 2018).

104 To protect pollinators and secure pollination services, researchers have suggested shifting to ecological intensification (Dicks et al., 2016; IPBES, 2016). The strategy involves actively managing 
ecological functions such as insect pollination and biological pest control for highly productive agriculture (Bommarco, Kleijn, \& Potts, 2013; Tittonell, 2014). Many practices under ecological intensification, such as the establishment of fallows and wildflower strips, diversification of cropping systems, and reduction of pesticide use, contribute to mitigating pollinator declines (KovácsHostyánszki et al., 2017). However, more knowledge is needed on the level of pollinator diversity and abundance required for desired pollination services and high yields, and how this can be reached in different crops and regions (Dicks et al., 2016; Kovács-Hostyánszki et al., 2017).

114 An almost completely unstudied question is how flowering time affects crop pollination (but see 115 Körösi et al., 2018; Pisanty, Afik, Wajnberg, Mandelik, \& Diekötter, 2015). If the availability of main 116 pollinators changes over summer, crop pollination could potentially be enhanced by adjusting crop

117 flowering time. For annual crops, this can be done by shifting sowing date within the limits set by 118 climatic conditions and crop growing times. The need for studying the method is emphasized by ongoing global climate change, which may induce phenological mismatches between crops and their pollinators (Kőrösi et al., 2018; Memmott, Craze, Waser, \& Price, 2007).

121

Turnip rape (Brassica rapa ssp. oleifera) is grown as oil and protein crop in Northern Europe and Canada. In Finland, it covers 28,500 hectares, corresponding to $1.4 \%$ of total cultivated area (Natural Resources Institute Finland, 2018). By contrast to oilseed rape (Brassica napus ssp. oleifera), the world's major Brassica crop, turnip rape is almost self-sterile requiring cross-pollination by wind or animals to set seed (Williams, 1978; Korpela, 1988). The main pollinators are Hymenoptera, especially honeybees (Apis mellifera), and Diptera (Brunel, Mesquida, Renard, \& Tanguy, 1994; Varis, 1995). In Finland, the long-term regional yields of turnip rape have decreased alongside with increasing use of neonicotinoid pesticides and decreasing complexity of agricultural landscapes, possibly due to disruption of pollination services (Hokkanen, Menzler-Hokkanen, \& Keva, 2017). 
The objective of this study was to examine the effects of landscape heterogeneity, pesticide use and flowering time on the insect pollination and yield of spring-sown turnip rape in boreal farmland. The study fields were situated in landscape types with two levels of heterogeneity, homogeneous and heterogeneous, and represented gradients of pesticide use intensity and flowering time. We hypothesized that turnip rape fields in heterogeneous landscapes, and with low pesticide use have high pollinator abundance and species richness, which enhance crop pollination and yield. Furthermore, we hypothesized that, due to the colony growth of social bees, the availability of turnip rape pollinators increases during summer, resulting in enhanced pollination and yield in late flowering fields.

\section{Materials and methods}

\subsection{Study fields}

The study was conducted in boreal farmland-forest mosaic landscapes of Southern Finland $\left(60^{\circ} 9^{\prime}-\right.$ $60^{\circ} 46^{\prime} \mathrm{N}, 23^{\circ} 49^{\prime}-26^{\circ} 2^{\prime} \mathrm{E}$ ) in the summer of 2017. A total of 34 turnip rape fields were selected from two landscape types differing in the percentage cover of arable land. A half of the fields were situated in homogenous landscapes with over $60 \%$ of arable land, and the other half in heterogeneous landscapes with less than $52 \%$ of arable land (Fig. 1, Table 1). Forest was the dominating uncultivated land use type (Table 1), and negatively correlated with arable land cover

152 (Pearson's $r=-0.82, p<0.001$ ). In boreal farmland, forests play a central role in modifying pollinator 153 diversity by providing flower-rich edge habitats and shelter from wind, and by channeling pollinator 154 movements (Öckinger, Lindborg, Sjödin, \& Bommarco, 2012; Toivonen et al., 2017). The cover of 155 arable land and other land use types was calculated for an area with a buffer of 500-m radius around 156 the central point of the study site using ArcGIS 10.5.1 (Esri, 2017). Although many pollinators can forage over larger distances than $500 \mathrm{~m}$, they usually prefer nearby resources when available 
158 (Couvillon et al., 2015; Redhead et al., 2016). The minimum distance between the fields was $1 \mathrm{~km}$.

159 Data on land use were derived from the CORINE Land Cover 2012 database (Finnish Environment

160 Institute, 2014). In addition, nine crop types, including turnip rape and oilseed rape, faba bean, red

161 clover, buckwheat, spring cereals, winter cereals, cultivated grassland, perennial fallow and bare

162 fallow were recorded during fieldwork. Shannon's diversity index $\left(H^{\prime}\right)$ for land use diversity was

163 calculated based on CORINE's level 3 land cover types (Finnish Environment Institute, 2014), and for

164 crop diversity based on the relative cover of the recorded crop types (Table 1).

165

166 Information on the farming methods on the turnip rape fields was gathered through farmer

167 interviews (Table 2). In both landscape types, there was a considerable variation among fields in

168 pesticide use and the starting date of flowering (Table 2). The latter was strongly related to sowing

169 date (see Table S1 in Supporting Information). The number of pesticide applications in a field,

170 including seed treatments and field sprayings with insecticides, herbicides and fungicides was used

171 as a proxy for pesticide use intensity (Dormann et al., 2007; Filippi-Codaccioni, Devictor, Bas, Clobert,

172 \& Julliard, 2010). Despite restrictions on the use of neonicotinoid insecticides in the European Union,

173 turnip rape seeds treated with neonicotinoids are used in Finland based on temporary permissions

174 (Tukes, 2016). Pesticide use intensity and flowering time were not correlated (Table S1), and they did not differ between the landscape types (Table 2).

176

177 The fields were sown with seven turnip rape varieties (Table 2), which did not differ in flowering

178 time (ANOVA, $\mathrm{df}=6, F=1.02, p=0.43$ ) or pesticide use intensity (ANOVA, $\mathrm{df}=6, F=0.76, p=0.61$ ).

$17935 \%$ of the fields had honey bee hives within the surrounding 500-m buffer. The number of honey

180 bee hives per turnip rape hectare did not differ between the landscape types (Table 2) and was not

181 correlated with pesticide use intensity or flowering time (Table S1).

182 


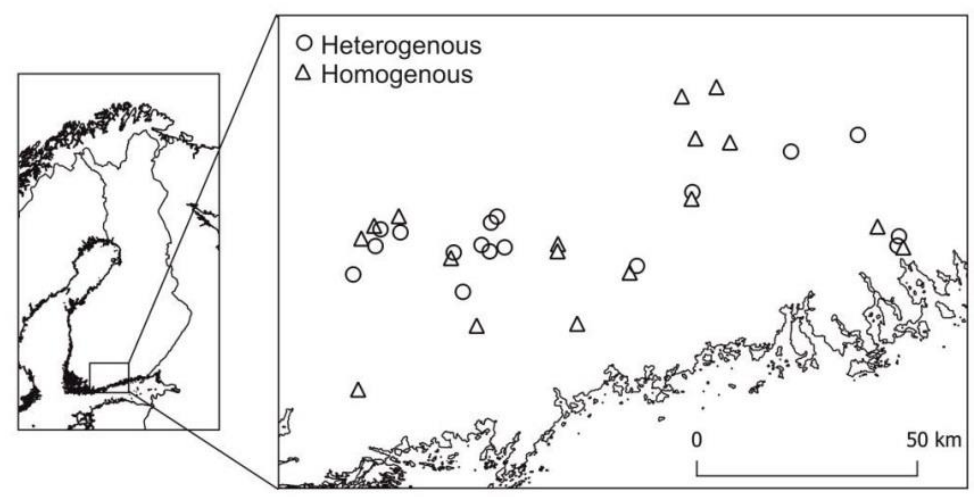

184 Figure 1. Locations of the 34 study fields representing two landscape types (characterized in Table 1) in Southern Finland.

186

187 Table 1. Comparison of the two landscape types. Percentage cover of arable land and forests were 188 calculated within 500-m buffer. Distance to forest was measured from the sampling plot closest to 189 forest. Shannon's diversity index $\left(\mathrm{H}^{\prime}\right)$ for land use diversity is based on CORINE's level 3 land cover 190 types (Finnish Environment Institute, 2014), and for crop diversity on the relative cover of crop 191 types.

192

\begin{tabular}{llllll}
\hline & \multicolumn{3}{c}{ Landscape types } & & \\
& \cline { 2 - 5 } & Homogenous & Heterogeneous & Welch two-sample t-test \\
& $(n=17)$ & $(n=17)$ & & & \\
\cline { 2 - 5 } Land use in 500-m buffer & mean [min, max] & mean [min, max] & $t$ & $d f$ & $p$ \\
\hline Arable land (\%) & $75[60,96]$ & $32[9,51]$ & -10.61 & $31.27<0.001$ \\
Turnip rape and oilseed rape (\%) & $19[3,52]$ & $9[2,22]$ & -2.83 & $22.07<0.01$ \\
Other insect-pollinated crops (\%) & $1[0,9]$ & $1[0,8]$ & -0.85 & $30.29 \mathrm{~ns}$ \\
Cereals (\%) & $44[15,68]$ & $18[0,38]$ & -5.39 & $28.36<0.001$ \\
Perennial grasslands (\%)* & $12[0,44]$ & $5[0,32]$ & -2.02 & $27.05 \mathrm{~ns}$ \\
Forest (\%) & $11[0,35]$ & $48[2,80]$ & 5.82 & $22.19<0.001$ \\
Distance to forest (m) & $203[79,421]$ & $21[7,71]$ & -8.71 & $17.30<0.001$ \\
Land use diversity (H) & $0.60[0.14,1.19]$ & $1.00[0.68,1.36]$ & 4.42 & $30.96<0.001$ \\
Crop diversity (H) & $0.88[0.47,1.18]$ & $0.82[0.46,1.30]$ & 1.76 & $31.91 \mathrm{~ns}$ \\
\hline
\end{tabular}

* Perennial grasslands included sown cultivated grasslands and perennial fallows. 
Table 2. Comparison of key farming characteristics of the studied turnip rape fields in the two landscape types. 'Pesticide use intensity' is the total number of pesticide applications in a field, including seed treatments and field sprayings with insecticides, herbicides and fungicides.

198

\begin{tabular}{|c|c|c|c|c|c|}
\hline \multirow{3}{*}{ Field characteristics } & \multicolumn{2}{|c|}{ Landscape types } & \multirow{2}{*}{\multicolumn{3}{|c|}{ Welch two-sample t-test }} \\
\hline & \multirow{2}{*}{$\begin{array}{l}\text { Homogenous } \\
(n=17)\end{array}$} & \multirow{2}{*}{$\begin{array}{l}\text { Heterogeneous } \\
(n=17)\end{array}$} & & & \\
\hline & & & $\mathrm{df}$ & $t$ & $p$ \\
\hline \multicolumn{6}{|l|}{ Mean [min, max] } \\
\hline Area (ha) & $9.9[2.1,33.3$ & $4.7[0.8,10.5$ & 19.01 & -2.16 & $<0.05$ \\
\hline Sowing date & 21.5. [10.5., 17.6. & 21.5. [10.5., 28.5 & 26.33 & -0.09 & ns \\
\hline Starting date of flowering & 5.7. [26.6., 22.7. & 2.7. [28.6., 15.7 & 31.29 & 1.17 & ns \\
\hline Honey bee hives / ha of turnip rape & $0.32[0.00,2.63$ & $0.39[0.00,2.64$ & 31.57 & 0.26 & ns \\
\hline Pesticide use intensity & $2.59[0,5$ & $2.41[0,5$ & 31.53 & -0.32 & ns \\
\hline \multicolumn{6}{|l|}{ Number of fields with } \\
\hline Seed treatment with neonicotinoids & 15 & 14 & & & \\
\hline Insecticide spraying & 10 & 10 & & & \\
\hline Herbicide spraying & 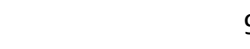 & 10 & & & \\
\hline Fungicide spraying & 2 & 5 & & & \\
\hline Organic farming & 2 & 3 & & & \\
\hline Reduced tillage & c & 3 & & & \\
\hline Turnip rape varieties (number of fields) & $\begin{array}{l}\text { Cordelia(5), } \\
\text { Juliet(7), Petita(5) }\end{array}$ & $\begin{array}{l}\text { Agat(1), Apollo(1), } \\
\text { Aurea(2), Cordelia(5), } \\
\text { Petita(6), Synthia(2) }\end{array}$ & & & \\
\hline
\end{tabular}

199

200

\subsection{Monitoring of flower visits}

202

203

In the study fields, pollinators were monitored in four $2 \times 2 \mathrm{~m}$ squares placed at 5 and $20 \mathrm{~m}$

distances from an open field edge (i.e. field edge not bordered by forest). At both distances from the edge, two squares were placed in parallel, $50 \mathrm{~m}$ from each other. In homogenous landscapes, the

206 field edge that situated farthest from forest was selected, whereas, in heterogeneous landscapes,

207 the open edge closest to forest was chosen. The systematic selection of the edges enabled to

208 strengthen the differences between the landscape types in arable land cover while avoiding

209 selection bias. The pollinator monitoring squares were marked with bamboo sticks. Three times

210 during flowering, every square was monitored for 5 minutes, and all pollinators visiting turnip rape

211 flowers and the number of visits where the insect touched the reproductive parts of the flower were 
212 recorded. Bumblebees and butterflies were identified to species, except for Bombus lucorum -group

213 (B. lucorum, B. terrestris, B. cryptarum and B. magnus) that was treated as a one species. Solitary

214 bees were recorded as a group. Syrphid flies were identified to subfamilies Syrphinae and

215 Eristalinae. Pollinator monitoring was carried out between 9 a.m. and 6 p.m., in weather conditions

216 when pollinator insects where active. Minimum temperature was $15^{\circ} \mathrm{C}$ in sunny or partly cloudy and

$21717^{\circ} \mathrm{C}$ in cloudy weather. Maximum wind speed was 5 on the Beaufort scale. Mean wind speed of

218 repeated measurements on an individual field ranged between 1.3 and 3.3.

219

220

\subsection{Measuring yield}

221

222 Yield was measured from eight open-pollinated and eight control plants per field. Before flowering,

223 two control plants at two meter distance from each pollinator monitoring square were covered with

224 a light fabric bag $(45 \times 75 \mathrm{~cm}$, white polyester voile, mesh size $0.32 \times 0.32 \mathrm{~mm})$ supported by a 1-m-

225 long bamboo stick. The bag excluded pollinator visits but allowed cross-pollination by wind within the bag. After flowering, the bags were removed. When the crop was ripe, the control plants were

227 collected. In addition, two open-pollinated plants were collected next to the marking stick of each pollinator monitoring square. Racemes per plant, siliques per raceme, and seeds per five lowest siliques of the main raceme were counted, after which the plants were dried at room temperature. Dry plants were harvested by hand, and seeds were weighed. To estimate weight per 100 seeds, the total seed weight per plant was divided by the number of siliques per plant and seeds per silique, and multiplied by 100 .

\subsection{Statistical analyses}

236 An information theoretic approach was used to analyze the effects of landscape type, pesticide use 237 intensity and flowering time on flower visits, pollinator species richness and yield. Since the 
explanatory variables got their values at field level, response variables were also aggregated by

239 fields. Thus, the response variables were the total number of flower visits and pollinator species

240 across four monitoring squares and three monitoring times in each field, average number of seeds

241 per silique, siliques per raceme and racemes per plant across the monitoring squares, and average

242 weight of 100 seeds and total seed yield per plant across the monitoring squares. For each response

243 variable, a total of nine competing models were constructed by including one to three of the

244 following variables as predictors: landscape type, pesticide use intensity, flowering time and two-

245 way interactions among them. Landscape type was a categorical variable with two levels,

246 homogenous and heterogeneous, while pesticide use intensity and flowering time were treated as

247 continuous.

248

249 Model types differed between the response variables: Generalized linear models (GLM) with Poisson 250 errors were used to model the number of flower visits and pollinator species richness. For flower 251 visits, quasi-likelihood estimation was used in the models because of overdispersion. For siliques per 252 raceme, racemes per plant and weight per 100 seeds, linear models (LM) were applied. For seeds per silique and total yield per plant, generalized least squares models (GLS) with normal errors and a spatial Gaussian correlation structure were selected, because the residuals of LMs were spatially autocorrelated. Spatial autocorrelation was tested by Moran's I test using the function moran.test() of the R package spdep (Bivand \& Piras, 2015). The Akaike Information Criterion corrected for small sample sizes (AICC) was used to compare the candidate models. For flower visits with quasi-Poisson models, AICc was replaced by the quasi-Akaike Information Criterion for small samples (QAICC). Model averaging was performed over all the models with $\Delta(\mathrm{Q}) \mathrm{AICc}<6$ by weighting parameter 260 coefficients according to their model probabilities (Akaike weights, $\mathrm{w}_{\mathrm{i}}$ ) (Burnham \& Andersson, 261 2002). The R package MuMIn (Barton, 2018) was applied for model selection and model averaging. 
In addition, the direct effects of flower visits and pollinator species richness on yield components and total yield per plant were analyzed with LMs, unless the residuals of the models were spatially autocorrelated, in which case GLS models with a spatial Gaussian correlation structure were selected. To examine the differences in yield components and total yield between open-pollinated plants and control plants with pollinator exclusion, linear mixed models (LMM) with field as a random factor were applied.

269

All analyses were conducted both with and without the latest flowering field with exceptionally high number of flower visits. The results of the analyses without the latest flowering field were included in Supplementary materials and reported in the main text if statistically significant explanatory variables differed from those identified in the analysis where all fields were included.

Models were fitted using the functions $\mathrm{g} / \mathrm{m}()$ and $\operatorname{Im}()$ of the R package stats (R Core Team, 2017), gls()of the package nlme (Pinheiro, Bates, DebRoy, Sarkar, \& R Core Team, 2017) and Imer() of the package Ime4 (Bates, Maechler, Bolker, \& Walker, 2015). All statistical analyses were run using $R$

\section{Results}

A total of 4674 flower visits by 744 pollinator individuals were recorded. The pollinators represented 21 species or groups (Table S2). Managed honeybees made $72 \%$ of all flower visits and were present

284 in $94 \%$ of the fields. The most frequent wild pollinators were bumblebees, with $16 \%$ of the flower 285 visits. 
289 The number of flower visits was best explained by the flowering time and the interaction between

290 flowering time and pesticide use intensity (Table 3, Table S3). Flower visits increased during

291 flowering season, and the increase was strongest in fields with low pesticide use (Fig. 2a). When the

292

latest flowering field was excluded from the analysis, the interactive effect of flowering time and

pesticide use intensity was lost, while the effect of flowering time remained (Table S4).

294

295

Landscape type and flowering time explained pollinator species richness (Table 3, Table S3). Species

richness was higher in heterogeneous than homogenous landscapes, and in late than early flowering

fields (Fig. 2b). When the latest flowering field was excluded, the landscape type effect was lost, while the effect of flowering time remained (Table S4).

299

300 Flowering time also predicted the number of seeds per silique (Table 3, Table S3), with higher seed

301 number in late than early flowering fields (Fig. 2c). The other yield components were not

302 significantly explained by any of the predictors (Table S3, Table 3). Total seed yield per plant was

303 significantly explained by pesticide use intensity (Table 3, Table S3), with increasing yield when pesticide use increased (Fig. 2d). When the latest flowering field was excluded, none of the yield variables responded statistically significantly to the predictors (Table S4). 
a)

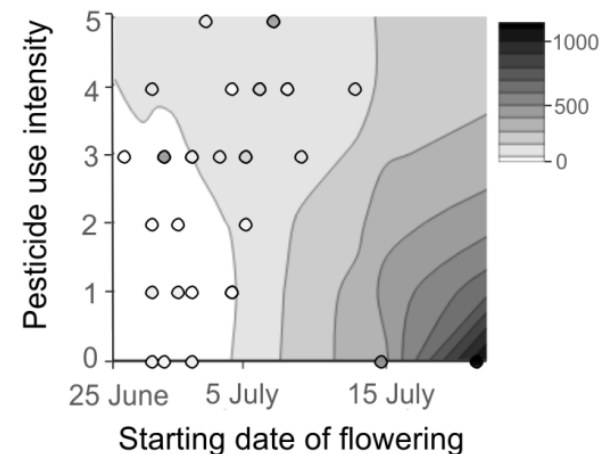

c)

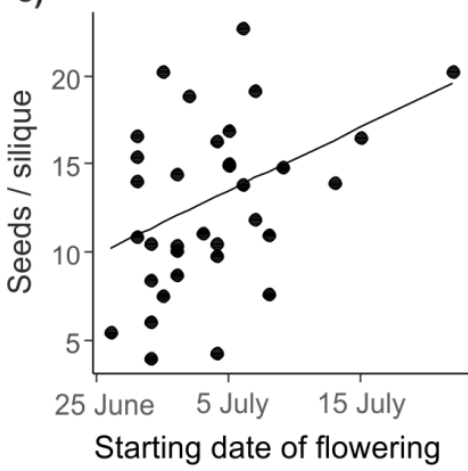

b)

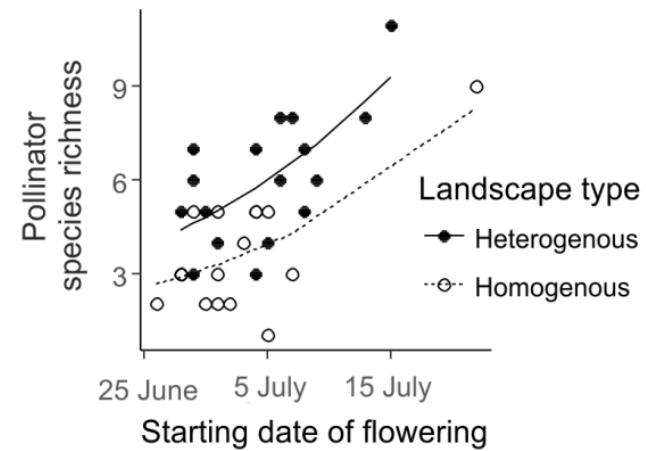

d)

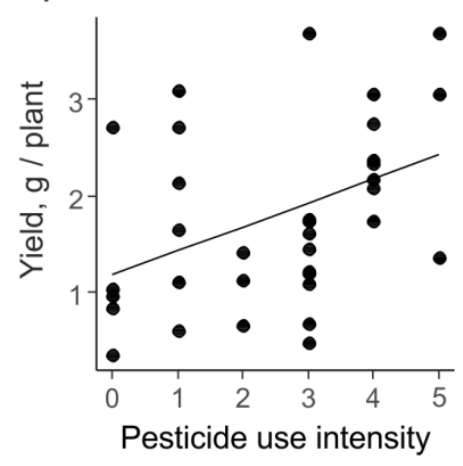

309 Figure 2. Turnip rape pollination and yield in relation to the best explanatory variables in model

310 averaging (Table 3): a) Total number of flower visits per field in relation to flowering time and

311 pesticide use, b) pollinator species richness in relation to flowering time and landscape type, c) the

312 number of seeds per silique in relation to the starting date of flowering, and d) yield per plant in

313 relation to pesticide use. The contour plot (a) and the lines in the scatterplots $(b-d)$ depict predicted

314 values based on respective models. Due to overlapping data points, the number of dots in the plots

315 is smaller than the number of study fields. 
317 Table 3. Results of model averaging explaining the number of flower visits and pollinator species

318 richness, yield components and total yield per plant. Model averaged parameter estimates were

319 calculated from a confidence set of models including all models with a $\Delta(\mathrm{Q}) \mathrm{AICc}<6$ (Table S3).

320 Bolded terms have a 95\% confidence interval (Cl) that do not include zero.

321

\begin{tabular}{|c|c|c|c|c|c|c|}
\hline Response variable & Model type & Parameter & Estimate & SE & Lower $\mathrm{Cl}$ & Upper Cl \\
\hline \multirow{7}{*}{ Flower visits } & GLM quasi- & & & & & \\
\hline & \multirow[t]{6}{*}{ Poisson } & (Intercept) & 3.52 & 0.50 & 2.52 & 4.53 \\
\hline & & Homogenous landscape $^{a}$ & -0.14 & 0.50 & -1.16 & 0.87 \\
\hline & & Pesticide use & 0.23 & 0.29 & -0.34 & 0.81 \\
\hline & & Flowering time & 0.12 & 0.03 & 0.07 & 0.18 \\
\hline & & Homogenous landscape ${ }^{a}$ : Flowering time & 0.03 & 0.05 & -0.07 & 0.14 \\
\hline & & Pesticide use: Flowering time & -0.03 & 0.02 & -0.07 & -0.00 \\
\hline \multirow{4}{*}{$\begin{array}{l}\text { Pollinator species } \\
\text { richness }\end{array}$} & \multirow[t]{4}{*}{ GLM Poisson } & (Intercept) & 1.33 & 0.19 & 0.94 & 1.73 \\
\hline & & Homogenous landscape $^{a}$ & -0.40 & 0.23 & -0.85 & -0.02 \\
\hline & & Flowering time & 0.04 & 0.01 & 0.01 & 0.07 \\
\hline & & Homogenous landscape ${ }^{a}$ : Flowering time & 0.00 & 0.01 & -0.05 & 0.06 \\
\hline \multirow[t]{6}{*}{ Seeds per silique } & \multirow[t]{6}{*}{ GLS } & (Intercept) & 9.64 & 1.72 & 6.13 & 13.15 \\
\hline & & Homogenous landscape ${ }^{a}$ & 1.01 & 1.74 & -2.55 & 4.56 \\
\hline & & Pesticide use & 0.25 & 0.63 & -1.04 & 1.53 \\
\hline & & Flowering time & 0.37 & 0.15 & 0.07 & 0.66 \\
\hline & & Homogenous landscape ${ }^{a}$ : Flowering time & -0.05 & 0.29 & -0.64 & 0.53 \\
\hline & & Pesticide use: Flowering time & -0.03 & 0.08 & -0.20 & 0.14 \\
\hline \multirow[t]{7}{*}{ Siliques per raceme } & \multirow[t]{7}{*}{ LM } & (Intercept) & 12.10 & 1.43 & 9.22 & 14.99 \\
\hline & & Homogenous landscape $^{a}$ & -0.27 & 1.12 & -4.37 & 2.85 \\
\hline & & Pesticide use & -0.05 & 0.36 & -1.26 & 1.02 \\
\hline & & Flowering time & -0.10 & 0.12 & -0.41 & 0.11 \\
\hline & & Homogenous landscape $e^{a}$ : Pesticide use & 0.03 & 0.22 & -0.54 & 2.62 \\
\hline & & Homogenous landscape ${ }^{a}$ : Flowering time & 0.01 & 0.07 & -0.23 & 0.69 \\
\hline & & Pesticide use: Flowering time & 0.00 & 0.02 & -0.21 & 0.06 \\
\hline \multirow[t]{6}{*}{ Racemes per plant } & \multirow[t]{6}{*}{ LM } & (Intercept) & 5.01 & 1.11 & 2.77 & 7.24 \\
\hline & & Homogenous landscape $^{a}$ & 0.07 & 0.67 & -2.23 & 2.68 \\
\hline & & Pesticide use & 0.33 & 0.35 & -0.29 & 1.12 \\
\hline & & Flowering time & -0.04 & 0.07 & -0.27 & 0.08 \\
\hline & & Homogenous landscape ${ }^{a}$ : Pesticide use & 0.04 & 0.20 & -0.45 & 1.67 \\
\hline & & Pesticide use: Flowering time & 0.00 & 0.02 & -0.04 & 0.14 \\
\hline \multirow{7}{*}{$\begin{array}{l}\text { Weight per } 100 \\
\text { seeds }\end{array}$} & \multirow[t]{7}{*}{ LM } & (Intercept) & 0.25 & 0.04 & 0.16 & 0.34 \\
\hline & & Homogenous landscape $^{a}$ & 0.00 & 0.04 & -0.12 & 0.13 \\
\hline & & Pesticide use & 0.01 & 0.01 & -0.02 & 0.04 \\
\hline & & Flowering time & 0.00 & 0.00 & -0.01 & 0.01 \\
\hline & & Homogenous landscape $e^{a}$ : Pesticide use & 0.00 & 0.01 & -0.09 & 0.01 \\
\hline & & Homogenous landscape $e^{a}$ : Flowering time & 0.00 & 0.00 & -0.02 & 0.01 \\
\hline & & Pesticide use: Flowering time & 0.00 & 0.00 & -0.00 & 0.01 \\
\hline \multirow[t]{3}{*}{ Yield per plant } & \multirow[t]{3}{*}{ GLS } & (Intercept) & 1.22 & 0.34 & 0.53 & 1.91 \\
\hline & & Homogenous landscape $^{a}$ & -0.01 & 0.15 & -0.78 & 0.65 \\
\hline & & Pesticide use & 0.24 & 0.12 & 0.00 & 0.47 \\
\hline
\end{tabular}


Flowering time

Homogenous landscape ${ }^{a}$ : Pesticide use

Pesticide use: Flowering time
$0.00 \quad 0.02 \quad-0.08$

$0.00 \quad 0.04 \quad-0.33$

$\begin{array}{lll}0.00 & 0.01 \quad-0.02\end{array}$
0.05

0.45 0.05

322

${ }^{a}$ As compared to heterogeneous landscape

323

324

3.2 Direct effects of insect pollination on yield

325

326

The number of seeds per silique increased, and racemes per plant decreased with increasing number

327

of flower visits (Table 4, Figure 3). When the latest flowering field was excluded from the analyses,

328 the effect on racemes was lost, while the effect on seeds per silique remained (Table S5). The other

329 yield components and total yield per plant were not affected by flower visits (Table 4). Pollinator

330 species richness did not affect any yield components (Table 4).

331

332 Control plants with pollinator exclusion produced $60 \%$ less yield than open-pollinated plants (Table

333 5). Seeds per silique, siliques per raceme and total seed weight were higher on open-pollinated

334 plants, whereas enclosed plants had higher number of racemes (Table 5, Table S6).

335

336

Table 4. Effects of flower visits and pollinator species richness on yield components and total yield

337 per plant.

\begin{tabular}{|c|c|c|c|c|c|c|c|c|c|}
\hline \multirow[b]{2}{*}{ Yield component } & \multirow{2}{*}{$\begin{array}{l}\text { Model } \\
\text { type }\end{array}$} & \multicolumn{4}{|c|}{ Flower visits } & \multicolumn{4}{|c|}{ Pollinator species richness } \\
\hline & & Estimate & SE & $t$ & $p$ & Estimate & SE & $t$ & $p$ \\
\hline Seeds per silique & GLS & 0.011 & 0.004 & 2.940 & $<0.01$ & 0.575 & 0.341 & 1.690 & ns \\
\hline Siliques per raceme & LM & -0.001 & 0.003 & -0.485 & ns & -0.210 & 0.260 & -0.805 & ns \\
\hline Racemes per plant & LM & -0.004 & 0.002 & -2.147 & $<0.05$ & -0.327 & 0.176 & -1.859 & ns \\
\hline Weight (g) per 100 seeds & LM & -0.002 & 0.002 & -1.002 & ns & -0.011 & 0.038 & -0.303 & ns \\
\hline Yield (g) per plant & GLS & -0.001 & 0.001 & -0.977 & ns & -0.059 & 0.069 & -0.842 & ns \\
\hline
\end{tabular}

338 

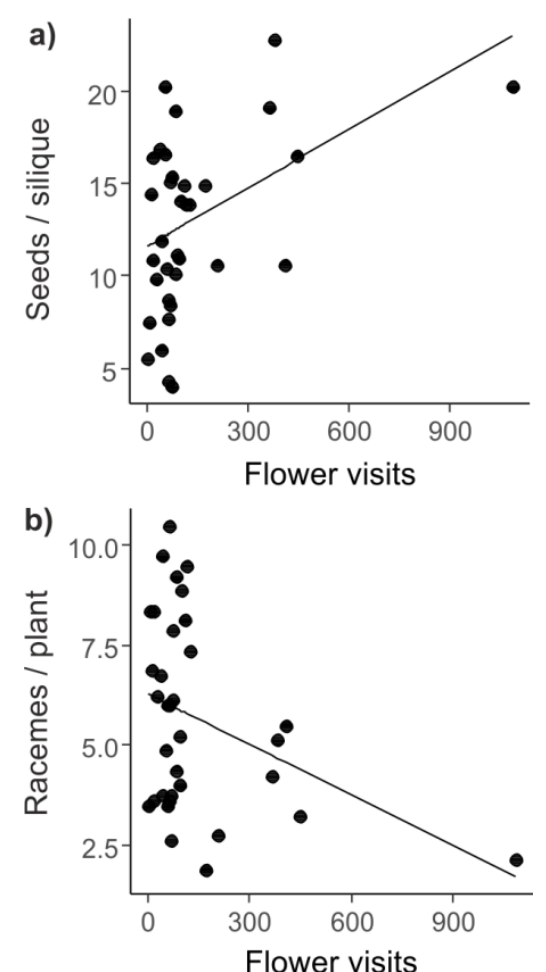

342 Figure 3. Seeds per silique (a) and racemes per plant (b) in relation to the total number of flower

343 visits per field. The lines depict predicted values based on the linear models.

Table 5. Comparison of the measured yield components and total yield between open-pollinated and bagged control plants.

\begin{tabular}{|c|c|c|c|c|c|c|c|c|c|}
\hline \multirow[b]{2}{*}{ Yield component } & \multirow{2}{*}{$\begin{array}{l}\text { Model } \\
\text { type }\end{array}$} & \multicolumn{2}{|c|}{ Open pollination } & \multicolumn{2}{|c|}{ Pollinator exclusion } & \multirow[b]{2}{*}{ Estimate $^{a}$} & \multirow[b]{2}{*}{ SE } & \multirow[b]{2}{*}{$t$} & \multirow[b]{2}{*}{$p$} \\
\hline & & Mean & SD & Mean & SD & & & & \\
\hline Seeds per silique & LMM & 12.74 & 4.78 & 5.14 & 2.32 & -7.60 & 0.75 & -10.15 & $<0.001$ \\
\hline Siliques per raceme & LMM & 11.02 & 3.44 & 7.24 & 2.30 & -3.78 & 0.63 & -5.97 & $<0.001$ \\
\hline Racemes per plant & LMM & 5.70 & 2.42 & 6.78 & 2.91 & 1.08 & 0.37 & 2.90 & $<0.01$ \\
\hline Weight (g) per 100 seeds & LMM & 0.24 & 0.11 & 0.32 & 0.28 & 0.08 & 0.05 & 1.66 & ns \\
\hline Yield (g) per plant & LMM & 1.77 & 0.92 & 0.69 & 0.57 & -1.08 & 0.14 & -7.61 & $<0.001$ \\
\hline
\end{tabular}

${ }^{a}$ Pollinator exclusion compared to open pollination 
Increasing pollinator visitation over the flowering period, and the associated increase in the number

352 of seeds per silique showed that turnip rape was best pollinated in late flowering fields. The colonies of the most important pollinators, honeybees and bumblebees, probably grew in July (Westphal, Steffan-Dewenter, \& Tscharntke, 2009; Ketola et al., 2015), resulting in increasing pollinator availability. Another explanation could be scarcity of floral resources in late summer, which would make turnip rape more attractive to pollinators (Heinrich, 1979). However, changes in the availability of wild flowers did not support this explanation, since flower abundance in the margins of the study fields increased towards the end of the turnip rape flowering season (Appendix S1). Analyzing changes in the availability of alternative crop resources for pollinators was not possible due to lack of data. The phenological overlap with pollinators is crucial for any insect-pollinated plant (Memmott, Craze, Waser, \& Price, 2007), but the effects of flowering time on crop pollination have received little attention in research (but see Kőrösi et al., 2018; Pisanty, Afik, Wajnberg, Mandelik, \& Diekötter, 2015). To our knowledge, this is the first study suggesting that crop pollination could be enhanced by shifting sowing time to better match crop flowering to the availability of the most important pollinators. A farmer's decision when to sow is usually driven by local weather and soil conditions, availability of farm machinery and workload (Kaukoranta \& Hakala, 2008). Climate change advances the timing of spring crop sowing at high latitudes, although not always at the same pace as the start of the thermal growing season (ibid.). This may affect crop-pollinator interactions, similarly to those

371 for wild plants and pollinators (Memmott, Craze, Waser, \& Price, 2007; Petanidou et al., 2014).

372 Shifting sowing date is also known as a cultural pest management strategy (Knodel, Olson, Hanson, 373 \& Henson, 2008; Lundin, Myrbeck, \& Bommarco, 2018). A recent study proposed early sowing as a 374 potential method to reduce flea beetle (Phyllotreta spp.) damage in spring oilseed rape (Lundin, 375 Myrbeck, \& Bommarco, 2018). Early sowing also reduces the risk of yield losses due to late crop 376 maturation. Trade-offs between different strategies should be studied to optimize the yield. 
378 Faster increase of flower visits in fields with low pesticide use is consistent with previous findings on 379 the negative effects of pesticides on crop pollination services (Stanley et al., 2015). Recent studies have found reduced colony growth and reproductive success of bees with exposure to neonicotinoid insecticides (Goulson, 2015; Rundlöf et al., 2015, Arce et al., 2017; Woodcock et al., 2017). Besides neonicotinoids, flower-visiting insects are routinely exposed to other insecticides, fungicides and herbicides, of which single and combined effects in field conditions are largely unknown (Botías, David, Hill, \& Goulson, 2017; Tosi, Costa, Vesco, Quaglia, \& Guido, 2018). Though not toxic to pollinators, fungicides may weaken their resistance to pathogens (Pettis et al., 2013) and cause synergistic mortality with insecticides (Raimets et al., 2018). Herbicides harm pollinators indirectly by reducing diversity of their food resources (Goulson, Nicholls, Botías, \& Rotheray, 2015). Reducing pesticide use without negative effects on crop productivity is possible in some production systems, especially if pesticide use is currently high (Lechenet, Dessaint, Py, Makowski, \& Munier-Jolain, 2017). In our study, the increase in total yield per plant with increasing pesticide use suggests that ecological intensification of turnip rape production requires introduction of enhanced non-chemical control methods for pests and weeds.

Pollinator species richness was higher in heterogeneous than homogenous landscapes, which is consistent with previous studies showing the dependency of pollinator diversity on natural and semi-natural habitats in agricultural landscapes (Ricketts et al., 2008; Garibaldi et al., 2011; Nicholson, Koh, Richardson, Beauchemin, \& Ricketts, 2017). High pollinator diversity has been shown to enhance the stability of pollination services in varying environmental conditions (Blüthgen \&

399 Klein, 2011; Brittain, Kremen, \& Klein, 2013), and in absence of honey bees (Winfree, Williams, 400 Dushoff, \& Kremen, 2007; Breeze et al., 2014). In our study, pollinator species richness did not 401 explain seed production of turnip rape. Thus, variation in pollination services was probably mainly 402 driven by differences in the abundance of common species, similarly to Genung et al. (2017). 
404 The effects of pesticide use and landscape type on insect pollination and yield lost their statistical 405 significance, though the patterns remained unchanged, when one field was excluded from the 406 analysis. More field studies, preferably under controlled conditions, are needed to confirm how 407 insect pollination of turnip rape is affected by pesticide use and landscape structure, and how 408 flowering time influences the effects.

410 Although the number of seeds per silique increased with increasing number of flower visits, total

411 yield per plant was not affected. This reveals that other factors than pollination, such as pest

412 pressure or nutrient availability had stronger effects on yield. Since information on pest and weed

413 abundance, soil characteristics and fertilization was not collected in the study, the main factor

414 limiting yield cannot be confirmed. Conventional management for high yields may conflict with 415 safeguarding pollination (Gagic et al., 2017): Pesticides reduce pest pressure, but simultaneously

416 impede pollination, and early sown plants, yet poorly pollinated, take advantage of the longer 417 growing season.

419 The relationship between insect pollination and total yield is further weakened by the high capacity of oilseed Brassicas to compensate for losses early in the season by producing more racemes and flowers, or by allocating resources into heavier seeds (Williams \& Free, 1979; McGregor, 1981; Zou et al., 2017). The opposite effects of flower visits on the number of seeds per silique and racemes per plant suggest that yield compensation occurred in our study. The yield compensation capacity

424 may buffer turnip rape production against the effects of pollinator shortage. However, it does not 425 prevent yield losses, when pollination sinks under a critical level, as was shown with the pollinator 426 exclusion bags, where few flowers managed to develop siliques. In addition, good pollination 427 enhanced resource use efficiency, since well-pollinated plants grew fewer racemes to reach the yield equal to that of poorly pollinated plants. Good insect pollination thus has potential to help reducing 
dependency on external production inputs such as chemical fertilizers in resource efficient cropping systems (Marini et al., 2015).

431

432

\section{Conclusions}

433

434 Shifting sowing time to increase the temporal match between crop flowering and the peak availability of the most important pollinators holds promise as a method to enhance pollination. Reduced pesticide use may also benefit crop pollination, but can result in the total yield reduction due to pests and weeds. Thus, ecological intensification of turnip rape production, which maintains or increases yield while conserving pollination services, requires the replacement of chemical pesticides with pollinator-friendly pest control methods. Understanding the ecological

440 interdependencies between agricultural practices, ecosystem services and yield in different crops

441 and regions is needed to find ways to reduce environmental degradation and to sustain agricultural 442 production in long-term.

\section{3}

\section{Authors' contributions}

446 All authors conceived the ideas and designed methodology. MT, HR and JT collected the data. MT

447 analyzed the data and led the writing of the manuscript. All authors contributed critically to the 448 drafts and gave final approval for publication.

Acknowledgements

452 We are grateful to farmers who participated in the research. We thank Tuula Lehtonen for 453 commenting on the research plan, Tarja Niemelä for sharing her expertise on turnip rape, and Ilse 


\section{Data accessibility}

458

459

Data available via the KNB Data Repository https://doi.org/10.5063/F1445JRF (Toivonen, Herzon, Rajanen, Toikkanen, \& Kuussaari, 2019).

461

462

\section{References}

463

464 Aizen, M. A., Garibaldi, L. A., Cunningham, S. A., \& Klein, A. M. (2009). How much does agriculture 465 depend on pollinators? Lessons from long-term trends in crop production. Annals of Botany, 103, 1579-1588. doi: 10.1093/aob/mcp076

467

468

Arce, A. N., David, T. I., Randall, E. L ., Rodrigues, A. R., Colgan, T. J., Wurm, Y., \& Gill, R.J. (2017).

469 Impact of controlled neonicotinoid exposure on bumblebees in a realistic field setting. Journal of

471

472

Barton, K. (2018). MuMIn: Multi-Model Inference. R package version 1.40.4.

473

474 Bates, D., Maechler, M., Bolker, B., \& Walker, S. (2015). Fitting Linear Mixed-Effects Models Using 475 Ime4. Journal of Statistical Software, 67, 1-48. doi: 10.18637/jss.v067.i01.

477 Baude, M., Kunin, W. E., Boatman, N. D., Conyers, S., Davies, N., Gillespi, M. A. K., ... Memmott, J. 478 (2016). Historical nectar assessment reveals the fall and rise of floral resources in Britain. Nature, $479530,85-88$. doi: 10.1038/nature16532 
481 Bivand, R., \& Piras, G. (2015). Comparing Implementations of Estimation Methods for Spatial

482 Econometrics. Journal of Statistical Software, 63, 1-36. doi: 10.18637/jss.v063.i18

483

484 Blüthgen, N., \& Klein, A.-M. (2011). Functional complementarity and specialisation: the role of

485 biodiversity in plant-pollinator interactions. Basic and Applied Ecology, 12, 282-291. doi:

$486 \quad$ 10.1016/j.baae.2010.11.001

487

488

Bommarco, R., Kleijn, D., \& Potts, S. G. (2013). Ecological intensification: harnessing ecosystem

489

services for food security. Trends in Ecology and Evolution, 28, 230-238. doi:

$490 \quad$ 10.1016/j.tree.2012.10.012

491

492 Botías, C., David, A., Hill, E. M., \& Goulson, D. (2017). Quantifying exposure of wild bumblebees to 493 mixtures of agrochemicals in agricultural and urban landscapes. Environmental Pollution, 222, 73494 82. doi: 10.1016/j.envpol.2017.01.001

495

496

Breeze, T. D., Vaissière, B. E., Bommarco, R., Petanidou, T., Seraphides, N., Kozák, L., ... Potts, S. G.

497 (2014). Agricultural policies exacerbate honeybee pollination service supply-demand mismatches across Europe. PLOS ONE, 9, e82996. doi: 10.1371/journal.pone.0082996

499

500 Brittain, C., Kremen, C. \& Klein, A. (2013). Biodiversity buffers pollination from changes in

501 environmental conditions. Global Change Biology, 19, 540-547. doi: 10.1111/gcb.12043

502

503 Brunel, E., Mesquida, J., Renard, M., \& Tanguy, X. (1994). Répartition de l'entomofaune pollinisatrice

504 sur des fleurs de colza (Brassica napus L) et de navette (Brassica campestris L): incidence du

505 caractère apétale de la navette. Apidologie, 25, 12-20. doi: 10.1051/apido:19940102 
507 Burnham, K. P., \& Anderson, D. R. (2002). Model selection and multimodal inference: a practical

508 information-theoretic approach (2nd ed.). Berlin, Germany: Springer. doi: 10.1007/b97636

509

510 Couvillon, M., J., Riddell Pearce, F. C., Accleton, C., Fensome, K. A., Quah, S. K. L., Taylor, E. L., \&

511 Ratnieks, F. L. W. (2015). Honey bee foraging distance depends on month and forage type.

512 Apidologie, 46, 61-70. doi: 10.1007/s13592-014-0302-5

513

514 Dicks, L., Viana, B., Bommarco, R., Brosi, B., Arizmendi, M., Cunningham, S., ... Potts, S. G. (2016). Ten

515 policies for pollinators. Science, 354, 975-976. doi: 10.1126/science.aai9226

516

517 Dormann, C. F., Schweiger, O., Augenstein, I., Bailey, D., Billeter, R., De Blust, G., ... Zobel, M. (2007).

518 Effects of landscape structure and land-use intensity on similarity of plant and animal communities.

519 Global Ecology and Biogeography, 16, 774-787. doi: 10.1111/j.1466-8238.2007.00344.x.

520

521

Esri (2017). ArcGIS Desktop: Release 10.5.1. Redlands, CA: Environmental Systems Research

522 Institute.

523

524 European Commission (2018). Protecting bees: EU set to completely ban outdoor use of pesticides harmful to bees. European Commission Daily News 27 / 04 / 2018. http://europa.eu/rapid/pressrelease_MEX-18-3583_en.htm Last accessed: 15.1.2019

527

528 Filippi-Codaccioni, O., Devictor, V., Bas, Y., Clobert, J., \& Julliard, R. (2010). Specialist response to 529 proportion of arable land and pesticide input in agricultural landscapes. Biological Conservation, 143, 530 883-890. doi: 10.1016/j.biocon.2009.12.035 
532 Finnish Environment Institute (2014). CORINE Land Cover 2012 database. Publication date:

533 11.11.2014. Land cover classification:

534 http://geoportal.ymparisto.fi/meta/julkinen/dokumentit/CorineLandCover2012_en.pdf

535

536

Gabriel, D., \& Tscharntke, T. (2007) Insect pollinated plants benefit from organic farming.

537

Agriculture, Ecosystems and Environment, 118, 43-48. doi: 10.1016/j.agee.2006.04.005

538

539 Gagic, V., Kleijn, D., Baldi, A., Boros, G., Bracht Jørgensen, H., Elek, Z., ... Bommarco, R. (2017).

540 Combined effects of agrochemicals and ecosystem services on crop yield across Europe. Ecology

541 Letters, 20, 1427-1436. doi: 10.1111/ele.12850

542

543 Garibaldi, L., Aizen, M. A., Klein, A. M., Cunningham, S. A., \& Harder, L. D. (2011). Global growth and

544 stability of agricultural yield decrease with pollinator dependence. Proceedings of the National

545 Academy of Sciences of the United States of America, 108, 5909-5914. doi:

$546 \quad 10.1073 /$ pnas.1012431108

547

548 Garibaldi, L., Steffan-Dewenter, I., Kremen, C., Morales, J., Bommarco, R., Cunningham, S., ... Klein, A. M. (2011). Stability of pollination services decreases with isolation from natural areas despite honey bee visits. Ecology Letters, 14, 1062-1072. doi: 10.1111/j.1461-0248.2011.01669.x

551

552 Genung, M. A., Fox, J., Williams, N. M., Kremen, C., Ascher, J., Gibbs, J., \& Winfree, R. (2017). The

553 relative importance of pollinator abundance and species richness for the temporal variance of

554 pollination services. Ecology, 98, 1807-1816. doi: 10.1002/ecy.1876

555

556 Godfray, H. C. J., Blacquière, T., Field, L. M., Hails, R. S., Potts, S. G., Raine, N.E., ... McLean, A.R.

557 (2015). A restatement of recent advances in the natural science evidence base concerning 
560

Goulson, D. (2015). Neonicotinoids impact bumblebee colony fitness in the field; a reanalysis of the

564 Goulson, D., Nicholls, E., Botías, C., \& Rotheray, E. L. (2015). Bee declines driven by combined stress

Heinrich, B. (1979). "Majoring" and "Minoring" by Foraging Bumblebees, Bombus Vagans: An

Hokkanen, H. M. T., Menzler-Hokkanen, I., \& Keva, M. (2017). Long-term yield trends of insectpollinated crops vary regionally and are linked to neonicotinoid use, landscape complexity, and Policy Platform on Biodiversity and Ecosystem Services.

579

580 Kaukoranta, T., \& Hakala, K. (2008). Impact of spring warming on sowing times of cereal, potato and 581 sugar beet in Finland. Agricultural and Food Science, 17, 165-176. doi: 
584 Ketola, J., Hakala, K., Ruottinen, L., Ojanen, H., Rämö, S., Jauhiainen, L., ... Pelkonen, S. (2015). The

585 impact of the use of neonicotinoid insecticides on honey bees in the cultivation of spring oilseed

586 crops in Finland in 2013-2015. Natural resources and bioeconomy studies, 73/2015. Helsinki,

587 Finland: Natural Resources Institute Finland (Luke).

588

589

Klein, A. M., Vaissiere, B. E., Cane, J. H., Steffan-Dewenter, I., Cunningham, S. A., Kremen, C., \&

590

Tscharntke, T. (2007). Importance of pollinators in changing landscapes for world crops. Proceedings

591

of the Royal Society B: Biological Sciences, 274, 303-313. doi: 10.1098/rspb.2006.3721

592

593 Knodel, J. J., Olson, D. L., Hanson, B. K., \& Henson, R. A. (2008). Impact of planting dates and

594 insecticide strategies for managing crucifer flea beetles (Coleoptera: Chrysomelidae) in spring-

595 planted canola. Journal of Economic Entomology, 101, 810-821. doi: 10.1093/jee/101.3.810

596

597 Kőrösi, Á., Markó, V., Kovács-Hostyánszki, A., Somay, L., Varga, Á., Elek, Z., Boreux, V., Klein, A.,

598 Földesi, R., Báldi, A. (2018). Climate-induced phenological shift of apple trees has diverse effects on

599 pollinators, herbivores and natural enemies. PeerJ, 6, e5269. doi: 10.7717/peerj.5269

600

601

Korpela, S. (1988). The influence of honeybee pollination on turnip rape (Brassica campestris) yield

602

and yield components. Annales Agriculturae Fenniae, 27, 295-303.

603

604 Kovács-Hostyánszki, A., Espíndola, A., Vanbergen, A., Settele, J., Kremen, C., \& Dicks, L. V. (2017).

605 Ecological intensification to mitigate impacts of conventional intensive land use on pollinators and

606 pollination. Ecology Letters, 20, 673-689. doi: 10.1016/j.tree.2012.10.012

607

608 Natural Resources Institute Finland (2018). Utilised Agricultural Area 2017.

609 http://stat.luke.fi/en/utilised-agricultural-area-2017_en Last accessed: 15.1.2019 
611 Lechenet, M., Dessaint, F., Py, G., Makowski, D., \& Munier-Jolain, N. (2017). Reducing pesticide use

612 while preserving crop productivity and profitability on arable farms. Nature Plants, 3, 17008. doi:

$613 \quad 10.1038 /$ nplants.2017.8

614

615 Lundin, O., Myrbeck, Å., \& Bommarco, R. (2018). The effects of reduced tillage and earlier seeding on

616 flea beetle (Phyllotreta spp.) crop damage in spring oilseed rape (Brassica napus L.). Crop Protection,

617 107, 104-107. doi: 10.1016/j.cropro.2017.10.019

618

619 Marini, L., Tamburini, G., Petrucco-Toffolo, E., Lindström, S. A., Zanetti, F., Mosca, G., ... Bommarco, 620 R. (2015). Crop management modifies the benefits of insect pollination in oilseed rape. Agriculture, 621 Ecosystems and Environment, 207, 61-66. doi: 10.1016/j.agee.2015.03.027

622

623 McGregor, D. I. (1981). Pattern of flower and pod development in rapeseed. Canadian Journal of 624 Plant Science, 61, 275-282. doi: 10.4141/cjps81-040

625

626

Memmott, J., Craze, P.G., Waser, N.M., \& Price, M.V. (2007) Global warming and the disruption of

627 plant-pollinator interactions. Ecology Letters, 10, 710-717. doi: 10.1111/j.1461-0248.2007.01061.x

628

629

Nicholson, C. C., Koh, I., Richardson, L. L., Beauchemin, A., \& Ricketts, T. H. (2017). Farm and

630 landscape factors interact to affect the supply of pollination services. Agriculture, Ecosystems and

631 Environment, 250, 113-122. doi: 10.1016/j.agee.2017.08.030

632

633 Öckinger, E., Lindborg, R., Sjödin, N. E., Bommarco, R. (2012). Landscape matrix modifies richness of

634 plants and insects in grassland fragments. Ecography, 35, 259-267. doi: 10.1111/j.1600-

$635 \quad 0587.2011 .06870 . x$ 
637 Park, M. G., Blitzer, E. J., Gibbs, J., Losey, J. E., \& Danforth, B. N. (2015). Negative effects of pesticides

638 on wild bee communities can be buffered by landscape context. Proceedings of the Royal Society B:

639 Biological Sciences, 282, 20150299. doi: 10.1098/rspb.2015.0299

640

641 Petanidou, T., Kallimanis, A. S., Sgardelis, S. P., Mazaris, A. D., Pantis, J. D., \& Waser, N. M. (2014).

642 Variable flowering phenology and pollinator use in a community suggest future phenological

643 mismatch, Acta Oecologica, 59, 104-111. doi: 10.1016/j.actao.2014.06.001

644

645 Pettis, J. S., Lichtenberg, E. M., Andree, M., Stitzinger, J., Rose, R., \& Vanengelsdorp, D. (2013). Crop

646 pollination exposes honey bees to pesticides which alters their susceptibility to the gut pathogen

647 Nosema ceranae. PLOS ONE, 8, e70182. doi: 10.1371/journal.pone.0070182

648

649 Pinheiro, J., Bates, D., DebRoy, S., Sarkar, D., \& R Core Team (2017)._nlme: Linear and Nonlinear 650 Mixed Effects Models_. R package version 3.1-131.

651

652

Pisa, L. W., Amaral-Rogers, V., Belzunces, L. P., Bonmatin, J. M., Downs, C. A., Goulson, D., ...

653

Wiemers, M. (2015). Effects of neonicotinoids and fipronil on non-target invertebrates.

654 Environmental Science and Pollution Research, 22, 68-102. doi: 10.1007/s11356-014-3471-x

655

656 Pisanty, G., Afik, O., Wajnberg, E., Mandelik, Y., \& Diekötter, T. (2015). Watermelon pollinators

657 exhibit complementarity in both visitation rate and single-visit pollination efficiency. Journal of

658 Applied Ecology, 53, 360-370. doi: 10.1111/1365-2664.12574

659 
663

Raimets, R., Karise, R., Mänd, M., Kaart, T., Ponting, S., Song, J., \& Cresswell, J. E. (2018). Synergistic

668

R Core Team (2017). R: A language and environment for statistical computing. R Foundation for

670 Statistical Computing. Vienna, Austria.

671

672 Redhead, J. W., Dreier, S., Bourke, A. F. G., Heard, M. S., Jordan, W. C., Sumner, S., ... Carvell, C. 673 (2016). Effects of habitat composition and landscape structure on worker foraging distances of five 674 bumble bee species. Ecological Applications, 26, 726-739. doi: 10.1890/15-0546

675

677 Viana, B. F. (2008). Landscape effects on crop pollination services: are there general patterns?

679

680 Rundlöf, M., Andersson, G. K., Bommarco, R., Fries, I., Hederström, V., Herbertsson, L., ... Smith, H. G.

681 (2015). Seed coating with a neonicotinoid insecticide negatively affects wild bees. Nature, 521, 77682 80. doi: $10.1038 /$ nature14420 
684 Stanley, D. A., Garratt, M. P. D., Wickens, J. B., Wickens, V. J., Potts, S. G., \& Raine, N. E. (2015).

685 Neonicotinoid pesticide exposure impairs crop pollination services provided by bumblebees. Nature, 686 528, 548-550. doi: 10.1038/nature16167

687

688

Svensson, B., Lagerlof, J., \& Svensson, B. G. (2000). Habitat preferences of nest-seeking bumble bees

689

(Hymenoptera: Apidae) in an agricultural landscape. Agriculture, Ecosystems and Environment, 77,

690

247-255. doi: 10.1016/S0167-8809(99)00106-1

691

692

Tittonell, P. (2014). Ecological intensification of agriculture - sustainable by nature. Current Opinion

693

in Environmental Sustainability, 8, 53-61. doi: 10.1016/j.cosust.2014.08.006

694

695

Toivonen, M., Herzon, I., Rajanen, H., Toikkanen, J., \& Kuussaari, M. (2019). Turnip rape pollination

696

data, Finland 2017. Knowledge Network for Biocomplexity. doi: 10.5063/F1445JRF

697

698

Toivonen, M., Peltonen, A., Herzon, I., Heliölä, J., Leikola, N., Kuussaari, M. (2017). High cover of

699

forest increases the abundance of most grassland butterflies in boreal farmland. Insect Conservation

700 and Diversity, 10, 321-330. doi: 10.1111/icad.12226

701

702

Tosi, S., Costa, C., Vesco, U., Quaglia, G., \& Guido, G. (2018). A 3-year survey of Italian honey bee-

703

collected pollen reveals widespread contamination by agricultural pesticides. Science of the Total

704

Environment, 615, 208-218. doi: 10.1016/j.scitotenv.2017.09.226

705

706 Tukes (2016). Tukesilta poikkeuslupa öljykasvien peittausaineille. Ammattilaistiedote 30.11.2016.

707 [Tukes grants a temporary authorization for seed treatment products of oilseed crops. Information

708 release 30.11.2016]. The Finnish Safety and Chemicals Agency (Tukes). https://tukes.fi/artikkeli/-

709 /asset_publisher/tukesilta-poikkeuslupa-oljykasvien-peittausaineil-1 Last accessed: 15.1.2019 
711 Varis, A.-L. (1995). Abundance, species composition and daily pattern of bees visiting field bean,

712 goat's rue and turnip rape in southern Finland. Agricultural Science in Finland, 4, 473-478.

713

714 Westphal, C. , Steffan-Dewenter, I., \& Tscharntke, T. (2009). Mass flowering oilseed rape improves

715 early colony growth but not sexual reproduction of bumblebees. Journal of Applied Ecology, 46,

716 187-193. doi: 10.1111/j.1365-2664.2008.01580.x

717

718 Williams, I. H. (1978). The pollination requirements of swede rape (Brassica napus L.) and of turnip

719 rape (Brassica campestris L). The Journal of Agricultural Science, 91, 343-348. doi:

$720 \quad 10.1017 /$ S0021859600046438

721

722 Williams, I. H., \& Free, J. B. (1979). Compensation of oil-seed rape (Brassica napus

723 L.) plants after damage to their buds and pods. The Journal of Agricultural Science, 92, 53-59. doi:

724

$10.1017 / 50021859600060494$

725

726

Winfree, R., Williams, N. M., Dushoff, J., \& Kremen, C. (2007). Native bees provide insurance against

727

ongoing honey bee losses. Ecology Letters, 10, 1105. doi: 10.1111/j.1461-0248.2007.01110.x

728

729

Wood, T. J., \& Goulson, D. (2017). The environmental risks of neonicotinoid pesticides: a review of the evidence post 2013. Environmental Science and Pollution Research International, 24, 1728517325. doi: 10.1007/s11356-017-9240-x

732

733 Woodcock, B. A., Bullock, J. M., Shore, R. F., Heard, M. S., Pereira, M. G., Redhead, J., ... Pywell, R. F.

734 (2017). Country-specific effects of neonicotinoid pesticides on honey bees and wild bees. Science, 735 30, 1393-1395. doi: 10.1126/science.aaa1190 
737 Zou, Y., Xiao, H., Bianchi, F. J. J. A., Jauker, F., Luo, S., \& van der Werf, W. (2017). Wild pollinators

738 enhance oilseed rape yield in small-holder farming systems in China. BMC Ecology, 17, 6. doi:

$739 \quad 10.1186 / s 12898-017-0116-1$

740 